\title{
Comparative Analysis of IFRS and US GAAP
}

\author{
Hanna Sanko
}

Professor, M.S. in Accounting and Audit, Colorado State University, Global Campus, USA

\section{Artem V. Koldovskyi}

Ph.D., Senior Lecturer, Department of Accounting and Audit, Sumy State University, Ukraine

\begin{abstract}
The paper presents a critical analysis of the needs for, reasonableness, and status of the convergence of U.S. Generally Accepted Accounting Principles (GAAP) and International Financial Reporting Standards (IFRS). Differences between IFRS and US GAAP are examined. The authors' conclusion is that it is both timely and necessary to converge and harmonize IFRS and U.S. GAAP into a single set of Global Accounting Standards. This will lead to a more stabilized and prosperous world economy and it will help to resolve many of the world's financial reporting problems.
\end{abstract}

Keywords: globalization, financial accounting principles, adaptation, IFRS, GAAP.

JEL Classification: H20.

(C) The Authors, 2017. This article is published with open access at ARMG Publishing.

\section{Introduction}

Before presenting a critical analysis of the history of the convergence project, a brief introduction of the development of the different accounting principles is discussed followed by the need to converge.

Development of US GAAP, IFRS and the need to Converge. In the United States (U.S.), the FASB (Financial Accounting Standards Board) issued Statements of Financial Accounting Standards (SFASs) and these specific accounting methods and procedures are known as GAAP (Generally Accepted Accounting Principles).

Detailed history of the Convergence Project. The IASB and FASB engaged in several steps to create a set of harmonized international standards to meet the growing needs of various stakeholders - the need to have comparable, quality, reliable, consistent financial statements for multinationals operating in cross-national environments, investors, creditors and the like. FASB's Short-term International Convergence Project, the Norwalk Agreement and the Roadmap to Convergence are three such steps.

Short-term International Convergence Project. U.S. GAAP is a rules-based set of accounting principles while the IFRSs are principles based. The Short-term International Convergence Project was created with the goal to "move a variety of individual differences between U.S. GAAP and IFRSs that are not within the scope of other major projects" (Schroeder, Clark \& Cathey, 2015, p. 95, para 4) and is still ongoing.

The Norwalk Agreement. The FASB and IASB held a joint meeting in Norwalk, Connecticut in September, 2002 and committed to develop high-quality, comparable, efficient common accounting standards. The boards agreed to achieve the goal of harmonizing the accounting standards in the following ways: undertaking a short-term project to remove a variety of differences between the U.S. GAAP and IFRSs; concurrently undertaking and addressing projects to eliminate the differences that remained unresolved by January 1, 2005; continuing on the work of convergence of projects that were ongoing; and encouraging coordinated efforts between the boards to meet the overall convergence goals (Schroeder, Clark \& Cathey, 2013).

Roadmap to Convergence. Following the Norwalk Agreement, in 2005, the Chief Accountant of the SEC described a roadmap to convergence for non-U.S. companies using the IFRSs and that were registered in the U.S., to eliminate the need to reconcile the financial statements. According to R.G. Schroeder, M.W. Clark and J.M. Cathey (2013), the roadmap to Convergence included the following seven milestones - improvements to accounting standards, funding the International Accounting Standards Committee Foundation, improving the ability to use interactive data for IFRS reporting (using eXtensible Business Reporting Language or XBRL language), creating awareness about IFRS and educating businesses and other business stakeholders in the US, start a limited use of IFRS in a small group of companies, SEC declaration in 2011 as to whether mandatory adoption of IFRS is feasible or not and finally deciding if mandatory adoption of IFRSs by large 
accelerated, non-accelerated and accelerated filers would be required (for the years ending December 2014, 2015 and 2016 respectively).

In 2007, the SEC decided to eliminate the requirement to file Form 20-F (reconciliation of financial statements prepared using IFRS to the principles as per U.S. GAAP) for foreign private issuers whose financial statements were prepared in accordance with IFRSs. However, this did not go through due to reluctance to converge form accounting professionals and stakeholders in the U.S. as well as the SEC. The differences between IFRSs and U.S. GAAP were one of the primary reasons for this and are discussed in detail in the following section.

\section{Literature review}

The scholarly literature concerning how U.S. GAAP and IFRS recognize revenue mostly focuses on the conceptual differences in principles. Along with the actual FASB and the International Accounting Standards Board (IASB) concepts and statements, many scholars in accounting have tried to indicate the major fundamental differences in how each recognizes revenue. Along with these articles that attempt to show the fundamental, conceptual differences in revenue recognition principles, many articles also evaluate the current situation regarding the efforts by the FASB and the IASB to converge the two standards.

These articles that try to specifically describe the fundamental differences between U.S. GAAP and IFRS are very important, but there also are many other scholarly pieces regarding recognizing revenue from a historical perspective. The seminal article that describes how companies should recognize revenue is J.H. Myers's The Critical Event and Recognition of Net Profit. In his article, J.H. Myers (1952) describes profit as being earned during an operating cycle. The cycle of buying inventory with cash to eventually resell makes up the operating cycle. The problem that now faces the company is for that company to decide at what point they recognize revenue. Should revenue be recognized at a specific point in the cycle, or should it be spread over the cycle in some manner? This specific point where a company decides to recognize revenue is what J.H. Myers refers to as the critical event. J.H. Myers states for some companies it is easy to define the critical event. For magazine publishers, they recognize revenue in the period the magazines are distributed. The exchange is fairly simple: the sale occurs, and cash is received at the time the subscription is booked (Myers, 1952). For software companies, the critical event is not that simple to define. For example, because of bundling of services and multiple-deliverable arrangements, it becomes more difficult to define the critical event for software companies when they recognize revenue.

Along with these more historical articles, there are also some articles that describe basic differences in U.S. GAAP and IFRS. The most important of these basic differences is that U.S. GAAP tends to be more rulesbased, while IFRS tends to be more principles-based. All of these articles' methodologies vary among comparative analyses, case studies, and descriptive analyses.

In terms of specific topic of revenue recognition differences in companies between U.S. GAAP and IFRS, it would be best to start with the historical papers. These historical papers will address the conceptual framework of the FASB, which is based on the very important approach of decision usefulness. The next step is under the conceptual framework to evaluate FASB Concepts Statement No. 5 regarding recognition and measurement concepts, including revenue recognition. Defining J.H. Myers's critical event will also be crucial in recognition and measurement, especially in terms of software revenue recognition. Next, the literature will focus on contrasting revenue recognition principles in general between the IASB and FASB, including how the two are trying to converge. Finally, the literature will correlate all of these components to recognizing software revenue for both U.S. GAAP and IFRS.

\section{Conceptual framework}

\section{Major differences between U.S. GAAP and IFRS applications}

While the wide adoption of IFRS in Europe and other non-U.S. countries created the need for quality, consistent, harmonized set of international standards in the U.S., it is easier said than done. In its July 2012 Work Plan, the SEC created a list of the major differences between U.S. GAAP and IFRS applications and these are presented as follows.

Rules versus principles based standards. The fundamental difference between the two sets of accounting standards is that the U.S. GAAP is a more detailed, rules-based set of standards while the IFRS is more of a principles-based set of standards. Therefore, E.A. Hlaciuc, V.A. Grosu, M.A. Socoliuc and G.A. Maciuca (2014) point out that the fundamental rules versus principles-based nature of the U.S. GAAP and IFRSs respectively, 
have resulted in differences in terms of some definitions of financial accounting terms and concepts, their recognition, assessments, alternatives, lack of requirements or recommendations, as well as differences in presentation.

Revenue recognition. The current revenue recognition guidelines for U.S. GAAP are very detailed, elaborate and industry-specific. On the other hand, for IFRS, there are two primary revenue standards and four revenuefocused interpretations, most of which can be broadly interpreted and applied without industry-specifications (PWC or PriceWaterhouse Coopers, 2014). For example, "U.S. GAAP guidance on software revenue recognition requires the use of vendor-specific objective evidence (VSOE) of fair value in determining an estimate of the selling price" unlike IFRS (PWC, 2014). Another example is that contingent pricing is not recognized as revenue (till the contingency is resolved and the revenue amount is fixed and realizable) unlike IFRS and therefore this impacts the timing and amount of revenue recognized under the two standards (PWC, 2014).

Research and development. As per U.S. GAAP, all research and development costs are expensed, while under the IFRS, certain research and development costs are allowed to be capitalized. This can cause significant differences in the timing and capitalization of research and development costs thereby impacting the subsequent amortization of the assets over their useful lives.

Impairment. As per U.S. GAAP, when assets are impaired, the treatment is considered permanent, while as per IFRS, impaired assets may be revalued.

Certain nonfinancial liabilities. Unlike IFRS, U.S. GAAP has a higher threshold for recognizing a probable contingent liability, as well as costs associated with disposal (as in a restructuring).

Inventory. As per U.S. GAAP, cost of inventories can be computed using LIFO (Last in first out), FIFO (First in first out) or Weighted average method. However, under the IFRS, cost of inventories cannot be computed using LIFO. This non-allowance of LIFO could have a significant impact on the operating results (and income taxes payable) for cross-border companies following the IFRS in the U.S.

Measurement of certain asset classes. Unlike IFRS, U.S. GAAP does not allow capitalization of certain types of assets, like the capitalization of internally developed intangibles and some property, plant and equipment. U.S. GAAP also allows the cost model to measure investment properties (unless the company meets certain criteria), unlike the IFRS, which allows for cost or fair value.

Income Taxes. For income taxes, fundamental differences exist in methodologies used under U.S. GAAP and IFRS. For instance, U.S. GAAP specifically addresses certain Uncertain Tax Positions (UTPs), while IFRS uses the general contingency model, which not only creates differences in the amounts of taxes, but also requires different disclosure requirements for UTPs.

Property, plant and equipment (PP\&E). As per U.S. GAAP, PP\&E are depreciated as a whole unit for its useful life, while under IFRS, "asset componentization" is allowed (where the total cost of an item can be depreciated separately over different useful lives.

Other general problems within the IFRS community of users. The principles-based approach of IFRS standards often creates inconsistency in the interpretation and application of the principles. Some of the other general problems within the IFRS community of users include - picking and choosing (for instance, several countries have accepted portions of the IFRS and not all the standards), potential of undue influence by the individuals and firms that are funding the IASB (International Accounting Standards Board), unenforceability aspect of principles-based IFRSs (when compared to the rules-based US GAAP), unequal application and enforcement of the IFRS amongst the users, and finally the inconsistent auditing approaches amongst the IFRS users.

The need to harmonize the differences required understanding the differences in the conceptual framework upon which the standards were based. In 2006 the IASB and FASB started the Conceptual Framework Project, to revise and unify the conceptual frameworks and the process is still ongoing, with 2015 marking the start of the fourth phase of conceptual framework project. "The FASB believes that, over time, the ultimate goal of convergence is the development of a unified set of high quality, international accounting standards that companies worldwide would use for both domestic and cross-border financial reporting" (McEnroe \& Sullivan, 2014, p. 19). Therefore, the total convergence of US GAAP and IFRS is delayed till all the above differences and issues can be investigated and resolved completely to the satisfaction of FASB and IASB. 


\section{Discussion of results}

\section{Detailed example of how transfer pricing can be used successfully by multinational corporations}

Multinational Corporations can use transfer pricing to minimize the corporate taxes of the consolidated parent company. The following example is adapted from the transfer pricing example in W.H. Hoffman, W.A. Raabe, J.E. Smith and D.M. Maloney (2014) and it illustrates in detail how transfer-pricing can be used successfully by multinational corporations to minimize the total tax of the group.

Description of the problem. ABC is a U.S. Corporation, which manufactures and sells finished goods to unrelated foreign customers. Let the sales revenue for ABC U.S. Corporation be $\$ 1000000$ and the cost of goods sold be $70 \%$ of sales. Hence, the net profit is $30 \%$ of sales or $\$ 300000$. This is taxed at the U.S. corporate tax rate of $35 \%$ and hence the total word-wide tax impact for the corporation is $\$ 105000$ (35\% of $\$ 300$ 000). These computations are depicted in Table 1 below.

Table 1. Total worldwide tax impact when transfer pricing is not used

\begin{tabular}{|l|c|}
\hline \multicolumn{2}{|c|}{ ABC U.S. Corporation } \\
\hline Sales Revenue & $\$ 1000000$ \\
Cost of Goods Sold (70\%) & 700000 \\
Profit & 300000 \\
U.S. Tax at 35\% on profit (i) & 105000 \\
Foreign Tax (ii) & 0 \\
Total Tax (i) (ii) & 105000 \\
\hline
\end{tabular}

Source: PriceWaterhouseCoopers.

How can ABC U.S. Corporation minimize its worldwide taxes using transfer pricing? Let us assume that ABC U.S. Corporation has a fully controlled subsidiary, XYZ Foreign Corporation, through which ABC sells finished goods. Since ABC controls XYZ Corporation, it uses transfer pricing for inter-company sales. Let us assume that $\mathrm{ABC}$ U.S. Corporation transfers finished inventory to XYZ Foreign Corporation for $\$ 800000$. Then, ABC makes a profit of $\$ 100000(\$ 800000-\$ 700000)$ in the United States and is taxed at $35 \%$ on $\$ 100$ 000. When XYZ sells the inventories at $\$ 1000000$ it makes a profit of $\$ 200000$ (\$1 $000000-\$ 800000)$. If the tax rate in the foreign country is $10 \%$, then the foreign taxes would be $\$ 20000$. Hence, using transfer pricing, the total worldwide taxes for ABC U.S. Corporation (the parent) would be $\$ 55000$ resulting in $\$ 50$ 000 savings in the total taxes when compared with Table 2 . These computations are presented in Table 2 below.

Critical Analysis. From Table 1 and 2, it is clearly observed how ABC U.S. Corporation can use transfer pricing successfully to minimize its total tax incidence. However, Sec. 482 of the Tax Code gives power to the IRS to determine the reasonableness of the transfer price of $\$ 800000$, and also question why the foreign corporation was shown to earn $\$ 200000$ of the profits while the U.S. parent is shown to have earned a profit of $\$ 100000$. The IRS has the power to adjust the transfer price upward if it doubts the ethics, reasonableness and other explanations for the transfer price determined by $\mathrm{ABC}$.

Table 2. Total worldwide tax impact when transfer pricing is used

\begin{tabular}{|c|c|c|c|c|}
\hline \multicolumn{2}{|c|}{ ABC U.S. Corporation } & \multicolumn{2}{|c|}{ XYZ Foreign Corporation } & \multirow[t]{2}{*}{ Total (I+II) } \\
\hline & I & & II & \\
\hline & & & & (See Note A) \\
\hline \multirow{2}{*}{$\begin{array}{l}\text { Sales Revenue } \\
\text { Cost of Goods Sold }(70 \%) \\
\text { Profit } \\
\text { U.S. Tax at } 35 \% \text { on profit }\end{array}$} & $\begin{array}{c}\$ 800000 \\
700000\end{array}$ & \multirow{2}{*}{$\begin{array}{l}\text { Sales Revenue } \\
\text { Cost of Goods Sold } \\
\text { Profit } \\
\text { Foreign Tax at } 10 \% \\
\text { Profit }\end{array}$} & $\begin{array}{c}\$ 100000 \\
800000\end{array}$ & $\begin{array}{c}\$ 1000000 \\
700000\end{array}$ \\
\hline & $\begin{array}{l}100000 \\
35000\end{array}$ & & $\begin{array}{c}200000 \\
20000\end{array}$ & $\begin{array}{c}300000 \\
55000\end{array}$ \\
\hline \multicolumn{4}{|c|}{$\begin{array}{l}\text { Total worldwide tax } \\
\text { Savings in tax due to use of transfer pricing }(\$ 105000-\$ 55000)\end{array}$} & $\begin{array}{l}55000 \\
50000\end{array}$ \\
\hline
\end{tabular}

Note A. The Total sales revenue in Table 2 does not include intercompany sales of $\$ 800000$ and the total cost of goods sold does not include intercompany sales or the cost of goods to the foreign corporation of $\$ 800000$, as per the rules for consolidation as per U.S. GAAP.

Source: PriceWaterhouseCoopers. 
Therefore, transfer-pricing strategies of multinational corporations undoubtedly have a very significant impact on the compliance risks associated with taxes and materiality aspect of financial statements.

\section{Methods of translating foreign currency financial statements}

With globalization and technological advancements, cross-border business operations have increased. At the same time, foreign currency fluctuations impact the currency exchange rates between the U.S. dollar and the other foreign currencies. When financial statements are prepared for multinational corporations, the parent company needs to translate the financial results of the foreign subsidiaries to the reporting currency used by the parent company before consolidating the results. At present, FASB Statement No. 52 (ASC 830) states specific guidelines to translate foreign currencies into U.S. dollars so that consolidated financial statements can be prepared (Baker, Christensen, \& Cottrell, 2012). Before discussing the different methods for translating foreign currency financial statements, a brief account of the methods used to translate foreign currency prior to ASC 830 are presented as follows.

Current-noncurrent method. Under this method, two different exchange rates are used to translate foreign currency financial statements. The current assets and short-term liabilities are translated at the exchange rate as at the balance sheet date, while the non-current assets and liabilities are translated using the historical exchange rates based on when the assets were acquired or when the liabilities were incurred (Schroeder, Clark \& Cathey, 2013).

Monetary-nonmonetary method. This method also uses two different exchange rates. Monetary items (like cash, receivables, payables, etc. but not inventory) are translated using the exchange rates as at the balance sheet date while non-monetary items are translated using historical exchange rates (Schroeder, Clark \& Cathey, 2013).

Current rate method. After the dollar was devalued in 1973, due to the resulting foreign currency fluctuations, two new methods - the current rate and the temporal method were introduced to translate foreign currency statements. The current rate method used the exchange rate as at the balance sheet date to translate all the assets (including fixed assets) and liabilities (Schroeder, Clark \& Cathey, 2013).

Temporal method. This method applies the principle of fair value to foreign currency translation and the exchange rates used to translate assets and liabilities are based on their temporal characteristics (Schroeder, Clark \& Cathey, 2013). Therefore, payables, receivables and money are translated at the exchange rate as at the balance sheet date while assets and liabilities are translated at the exchange rates to which the "money prices pertain" (Schroeder, Clark \& Cathey, 2013).

FASB SFAS No. 8. As per as FASB's Statement of Financial Accounting Standard 8, the objective of foreign currency translation is to measure the assets, liabilities, revenue and expenses originally measured in a foreign currency, in U.S. dollars as per the principles of U.S. GAAP. According to R.G. Schroeder, M.W. Clark and J.M. Cathey (2013), the temporal method (as explained in the previous paragraph) of foreign currency translation satisfied the general objectives of SFAS No. 8 most closely. However, when foreign currency transactions were translated using SFAS No. 8, costs and revenues were not being matched appropriately and translation of inventory using historical rates often caused economically different results from reality. Eventually SFAS No. 8 was replaced with FASB Statement No. 52.

FASB Statement No. 52 (ASC 830). FASB Statement No. 52 ASC 830 "Foreign Currency Translation" emphasizes on retaining the financial results and relationships in foreign financial statements when they are converted into U.S. dollars. For example, if the income statement shows a net profit in a foreign currency, then the translated income statement should also show a net profit after converting the sales revenue and all the costs and expenses. FASB ASC 830 uses the functional currency approach. According to R.E. Baker, T.E. Christensen and D.M. Cottrell (2012), functional currency is defined as "the currency of the primary economic environment in which the entity operates...generates and receives cash" (p.450, para 1). Cash flows, sale prices, sale, markets, expenses, and financing and intercompany transactions are six indicators that must be assessed to determine a company's functional currency (Baker, Christensen, \& Cottrell, 2012). For example, if a foreign entity has few intercompany transactions with the parent, most of the transactions are done using the local currency, and the cash generated is not returned to the parent in the U.S. on a regular basis, then the local currency would be considered as the functional currency of the entity. However, in case the foreign entity's operations are in a highly inflationary economies (like that of Argentina and Peru), then the reporting currency of the U.S. parent (that is U.S. dollars) should be used as the functional currency as per FASB (Baker, 
Christensen, \& Cottrell, 2012). Additionally, once the functional currency is chosen, it must be followed consistently in general.

Two different methods can be used to restate the financial statements of foreign entities into U.S. dollars - the translation method and the remeasurement method. These are explained below.

Translation method. Translation method is usually used when the local currency is the functional currency of the foreign entity. The current rate method (as explained before) is used to translate foreign currency financial statements and any translation adjustment (gain or loss) is reported under comprehensive income in the consolidated financial statements of the parent company in U.S. dollars (Baker, Christensen, \& Cottrell, 2012). For example, the financial results of a German subsidiary of a U.S. parent company would need to be translated from Euro to U.S. Dollars based on the exchange rate (conversion rate of Euro to U.S. dollar) as at the balance sheet date of the reporting company.

Remeasurement method. Remeasurement method is used when the foreign entity uses a reporting currency different from the functional currency (Baker, Christensen, \& Cottrell, 2012). The temporal method (as explained before) is used to remeasure the financial statements from the local currency into the functional currency and if the functional currency is the U.S dollar, then no further translation is needed thereafter; while if the functional currency is not the U.S. dollar, then the financial statements are translated (after remeasurement) into U.S. dollars using the current rate method (Baker, Christensen, \& Cottrell, 2012). Additionally, any imbalance that results due to remeasurement is included in the income statement to compute the net income. For example, if a Mexican sales branch of a U.S. parent uses Mexican Peso for reporting and recording transactions, but uses the U.S. dollar as functional currency, then for the purpose of consolidation of the financial statements, the Mexican entity's financial statements must be remeasured into the functional currency using the temporal method and since the functional currency is U.S. dollars, no further translation would be required for the purpose of consolidation.

Financial statement presentation of translation adjustment. As indicated previously, the translation adjustment resulting due to translation of the financial statements of a foreign entity into U.S. dollars are reported as part of the entity's comprehensive income as per FASB statement no. 130 (ASC 220) (Baker, Christensen, \& Cottrell, 2012).

International accounting standards for translation of foreign currency statements. The rules for foreign currency translation are mostly contained in the revised IAS (International Accounting Standard) No.21 "The Effects of Changes in Foreign Exchanges Rates" issued by the IASB. The rules are mostly similar to that of U.S. GAAP contained in SFAS no. 52. According to R.G. Schroeder, M.W. Clark and J.M. Cathey (2013), foreign currency transactions are initially recorded at historical exchange rates, and finally monetary items are reported using the exchange rate as at the balance sheet date, while nonmonetary items are reported at either the historical rate or the current rate. The resulting exchange differences are classified as stockholders' equity (till the time the investment in foreign entity is disposed and when it is disposed, the exchange gain or loss is recognized as income or loss).

Concluding points - critical summary of analysis. Translating foreign currency financial statements involves complicated processes. Therefore, R.G. Schroeder, M.W. Clark and J.M. Cathey (2013), pointed out that when investors analyze the impact of foreign currency translation information in financial statements, they must understand that the process if a "mixture of exceptional complexity" (p. 581). The two primary ways in which foreign currency financial statements are translated as per FASB are using the translation method and the remeasurement method, depending on the foreign entity's functional currency. However, what is significant is that, as per FASB Statement No. 52, the relationship between the financial results are retained or preserved when the foreign financial statements are translated into U.S. dollars for the purpose of consolidation.

\section{Conclusions}

Every country has its individual set of regulations and rules for financial reporting and accounting. For that reason, when a company decides to involve an International capital, the regulations and rules of that other country will apply and this in turn will require that the company is in a situation to realize the differences between the rules governing financial reporting. The authors have systemized the main differences between IFRS and US GAAP, which are presented in the Table 3 below. 
Table 3. Differences between IFRS and US GAAP

\begin{tabular}{|c|c|}
\hline International Financial Reporting Standards & Generally Accepted Accounting Principles \\
\hline \multicolumn{2}{|c|}{ 1. Financial statements } \\
\hline $\begin{array}{l}\text { Two years consolidated financial statements with excep- } \\
\text { tions in limited circumstances for entities which may pre- } \\
\text { sent single entity parent company financial statements } \\
\text { with CFS. }\end{array}$ & $\begin{array}{l}\text { Single entity parent company-stand alone to present } 2 \text { years CFS and } \\
\text { publish listed companies to prepare CFS with standalone financial } \\
\text { statements. }\end{array}$ \\
\hline \multicolumn{2}{|c|}{ 2. Position statements } \\
\hline $\begin{array}{l}\text { No particular format unless liquidity presentation provides } \\
\text { reliable information. }\end{array}$ & $\begin{array}{l}\text { No particular format according to AS but prescribed by companies act } \\
\text { and other industry regulations. }\end{array}$ \\
\hline \multicolumn{2}{|c|}{ 3. Income statements } \\
\hline $\begin{array}{l}\text { Expenditure is presented in one of the two formats- func- } \\
\text { tions or nature otherwise no formats. }\end{array}$ & $\begin{array}{l}\text { Disclosed in accordance with companies act and accounting standards. } \\
\text { Industry specific formats are also available. }\end{array}$ \\
\hline \multicolumn{2}{|c|}{ 4. Cash flow statement and format and methods } \\
\hline $\begin{array}{l}\text { To use direct and indirect method with standard heading } \\
\text { with limited guidance on items. }\end{array}$ & $\begin{array}{l}\text { Same as International Financial Reporting Standards. Listed compa- } \\
\text { nies require indirect method And insurance companies require direct } \\
\text { method. }\end{array}$ \\
\hline \multicolumn{2}{|c|}{ 5. Cash and cash equivalents definition } \\
\hline $\begin{array}{l}\text { Cash and equivalents with maturity of } 3 \text { months or less and } \\
\text { includes bank overdraft. }\end{array}$ & Same as IFRS but excludes bank overdraft \\
\hline \multicolumn{2}{|c|}{ 6. Acquired intangible assets } \\
\hline $\begin{array}{l}\text { If recognized-capitalist and to be amortized over useful } \\
\text { life. If useful life is not certain to be reviewed for impair- } \\
\text { ment for rare items revaluations are granted. }\end{array}$ & $\begin{array}{l}\text { Same as IFRS but useful life not to exceed } 10 \text { years no revaluation to } \\
\text { be done. More than 10-year test of impairment is necessary. }\end{array}$ \\
\hline \multicolumn{2}{|c|}{ 7. Internal tangible assets } \\
\hline $\begin{array}{l}\text { Research expenses are incurred cost. Capitalized and mor- } \\
\text { alized. Development cost when specific areas is met. }\end{array}$ & Same. \\
\hline \multicolumn{2}{|c|}{ 8. Financial assets } \\
\hline Held for maturity - carried at amortized cost. & $\begin{array}{l}\text { Long term investments }=\text { cost less impairment, any reduction credited } \\
\text { to income statements. Industries specified banking, insurance. }\end{array}$ \\
\hline \multicolumn{2}{|c|}{ 9. Liabilities provision and general } \\
\hline $\begin{array}{l}\text { Recorded if outflow can be correctly estimated and prov- } \\
\text { able. Provision discounted to present value when time } \\
\text { value is effected. }\end{array}$ & Same but discounting is not permitted. \\
\hline \multicolumn{2}{|c|}{ 10. EPS (earning per share) } \\
\hline $\begin{array}{l}\text { Share options and warrants attract treasury share method } \\
\text { and for diluted earning per share weighted average poten- } \\
\text { tial dilutive shares are denominators. }\end{array}$ & $\begin{array}{l}\text { Same. Only where advance shares application money if received is di- } \\
\text { lutive potential equity shares. }\end{array}$ \\
\hline \multicolumn{2}{|c|}{ 11. Revenue recognition } \\
\hline $\begin{array}{l}\text { Several criteria are applied with special reference to cases } \\
\text { where risk and rewards have been transferred. }\end{array}$ & Conceptually difference arises. \\
\hline
\end{tabular}

\section{References}

1. American Institute of Certified Public Accountants (2016). IFRS FAQs. Retrieved from http://www.ifrs.com/ifrs_faqs.html\#q3

2. Baker, R.E., Christensen, T.E., \& Cottrell, D.M. (2012). Essentials of advanced financial accounting $\left(1^{\text {st }} \mathrm{ed}.\right)$. New York, NY: McGraw-Hill/Irwin.

3. Deloitte (2015). Use of IFRS by jurisdiction. Retrieved from http://www.iasplus.com/en/resources/ifrstopics/use-of-ifrs.

4. Hlaciuc, E., Grosu, V., Socoliuc, M., \& Maciuca, G. (2014). Comparative study regarding the main differences between US GAAP and IFRS. USV Annals Of Economics \& Public Administration, 14(2), 140-145.

5. Hoffman, W.H., Raabe, W. A., Smith, J.E., \& Maloney, D.M. (2014). Corporations, partnerships, estates \& trusts $\left(37^{\text {th }}\right.$ ed.). Mason, $\mathrm{OH}$ : South-Western Cengage Learning.

6. Hughes, E., \& Nicholls, W. (2010). The different methods of TP: Pros and cons. Retrieved from http://www.taxjournal.com/tj/articles/different-methods-tp-pros-and-cons.

7. McEnroe, J.E., \& Sullivan, M. (2014). The rise and stall of the U.S. GAAP and IFRS convergence movement. CPA Journal, 84(1), 14-19. 
8. McGowan, J.R., \& Wertheimer, M. (2009). The effect of IFRS implementation on tax. Retrieved from http://www.thetaxadviser.com/issues/2009/dec/theeffectofifrsimplementationontax.html.

9. McKinley, J., \& Owsley, J. (2013). Transfer pricing and its effect on financial reporting. Retrieved from http://www.journalofaccountancy.com/issues/2013/oct/20137721.html.

10. PriceWaterhouseCoopers (2014). IFRS and US GAAP similarities and differences. Retrieved from https:// www.pwc.com/us/en/issues/ifrs-reporting/publications/assets/ifrs-and-us-gaap-similarities-and-differences2014.pdf.

11. Satin, D., \& Huffman, T. (2015). FASB and IASB convergence: Asymptotic relationship or transmogrification? Academy Of Accounting \& Financial Studies Journal, 19(2), 239-249.

12. Schroeder, R.G., Clark, M.W., \& Cathey, J.M. (2013). Financial reporting disclosures and ethical responsibilities. In Financial accounting theory and analysis: Text and cases (11th ed.). Hoboken, N.J.: Wiley.

13. Tsakumis, G.T., Campbell, D.R.Sr., \& Doupnik, T.S. (2009). IFRS: Beyond the Standards. Retrieved from http://www.journalofaccountancy.com/issues/2009/feb/ifrsbeyondthestandards.html.

14. Wharton. (n.d.). Transfer pricing. Retrieved from http://finance.wharton.upenn.edu/ bodnarg/courses/wembaw/readings/Transfer_pricing_chapter.pdf. 